\title{
Effect of oocyte in vitro maturation interval on subsequent ICSI embryo quality and development.
}

\author{
MB Rodríguez ${ }^{1,3},{ }^{*}$, GJ Clérico ${ }^{2,3}$, A Gambini ${ }^{1,3}$, D Rodriguez, G Taminelli ${ }^{2}$, JC Veronesi ${ }^{4}, \mathrm{~S}$ \\ Fernandez ${ }^{4}, M$ Sansinena ${ }^{2,3}$, and D Salamone ${ }^{1,3}$. \\ ${ }^{1}$ Laboratorio de Biotecnología Animal, Facultad de Agronomía, Universidad de Buenos Aires, \\ Buenos Aires, Argentina. ${ }^{2}$ Laboratorio de Reproducción Animal, Facultad de Ingeniería y \\ Ciencias Agrarias, Pontificia Universidad Católica Argentina, Buenos Aires, Argentina. ${ }^{3}$ Consejo \\ Nacional de Investigaciones Científicas y Técnicas (CONICET), Argentina. ${ }^{4}$ Frigorífico Equino \\ Lamar, Lamar S.A., Mercedes, Buenos Aires, Argentina.
}

\section{Introduction}

Demand for in vitro equine embryo production by ICSI has increased in clinical reproduction over the last 5 years. However, the efficiency of this technique remains variable with reported blastocyst rates between 10 and $41 \%$. Oocytes recovered by transvaginal follicular aspiration from donor mares are valuable and limited, and they are often collected from immature follicles. These oocytes require further in vitro maturation in order to be competent to be fertilized and reach the blastocyst stage. For this reason, it is crucial to determine the optimal time to perform ICSI after onset of oocyte maturation. Different in vitro maturation intervals have been reported to produce ICSI embryos in horses (28-30h[1]; $36 \mathrm{~h}$-[2]; $38 \mathrm{~h} \mathrm{[3];} \mathrm{20-22} \mathrm{h-} \mathrm{[4]).} \mathrm{However,} \mathrm{there} \mathrm{is}$ no consensus about the optimal maturation interval to produce high quality embryos.

An important aspect of preimplantation embryo development is cell differentiation, with the formation of the inner cell mass (ICM) and the trophectoderm (TE). The Hippo signaling pathway has been shown to play an important role in mice and cattle $[5,6]$, but it has not been described in horses to date. Nuclear localization of a protein called Yes-associated protein 1 (YAP1) in TE cells affects the expression of CDX2 and subsequent cell differentiation. YAP1 functions as a critical co-activator for TE development in the nucleus of TE cells, but in the inner cell mass, it stays mainly in the cytoplasm as a phosphorylated inactive form [6].

In this study, we aimed to evaluate developmental rates and quality of ICSI embryos produced from oocytes which exhibited extrusion of first polar body early in IVM (Group I, 22 to $24 \mathrm{~h}$ ) or late (Group II, 28 to $30 \mathrm{~h}$ ). Blastocyst development and size were recorded. Embryo quality was assesed by analysis of apoptotic cells (TUNEL assay), and expression and distribution of YAP-1 by immunoflourescence (IF).

\section{Materials and Methods}

\subsection{Oocyte recovery and In Vitro Maturation (IVM)}

Immature COC's were recovered by follicular scraping from abattoir-derived ovaries. The COC's were recovered from the pellet of the $50 \mathrm{ml}$ tubes and placed in $50 \mathrm{ul}$ drops of IVM medium (TCM199 containing 10\% FBS, $1 \mu \mathrm{l} / \mathrm{ml}$ insulin-transferrin-selenium, $1 \mathrm{mM}$ sodium pyruvate, $100 \mathrm{mM}$ cysteamine, $0.1 \mathrm{mg} / \mathrm{mL} \mathrm{FSH}$, and $2 \%$ antibiotic-antimycotic) under mineral oil. Cumulus cells were removed from all oocytes after $22 \mathrm{~h}$ of IVM by pipetting, oocytes were then classified as matured (visible first polar body), immature (no polar body) or degenerated (cell membrane damaged).

\subsection{ICSI and embryo culture}

Oocytes that matured before $24 \mathrm{~h}$ were subjected to ICSI and included in experimental Group I: $22-24 \mathrm{~h}$. Remaining immature oocytes were kept in maturation medium until $28-30 \mathrm{~h}$, followed by a re-evaluation for first polar body extrusion. Those oocytes that matured were subjected to ICSI and included in the experimental Group II: 28-30 h. Oocytes that matured after $30 \mathrm{~h}$ was 
not used for this experiment. Frozen semen from a single fertile stallion was used for this experiment. Presumptive zygotes were cultured in DMEM F12/Global Total ${ }^{\circledR}$ with $6 \%$ FBS. Cleavage were recorded on day 5 of culture, media was refreshed and blastocysts were classified, measured and fixed for IF between day 7 and 9 of culture.

2.3 Embryo size, cell number, TUNEL, and YAP-1.

Blastocyst diameter was measured using an eyepiece micrometer under the microscope (Nikon TiU inverted microscope, at $40 \mathrm{X}$ magnification). The zona pellucida was removed using protease $(15 \mathrm{mg} / \mathrm{ml})$ and embryos were fixed in a $4 \%$ solution of paraformaldehyde for subsequent TUNEL assay (DeadEnd ${ }^{\mathrm{TM}}$ Fluorometric TUNEL System) and IF (YAP-1 antibody, Secondary Antibody, Alexa Fluor® 555, \# A-28180).

\subsection{Image analysis}

The total cell count, TUNEL+ cell count, and YAP1 intensity measurements were performed with FIJI image processing software. For YAP1, the global intensity of each embryo was measured and divided for its area.

\subsection{Statistical analysis}

For the comparison of blastocyst size, cell count and TUNEL+ cells t-Student's test was used; a Chi-squared test was used blastocyst production and Kruskal-Wallis for YAP1 intensity.

\section{Results}

\subsection{In vitro preimplantation embryo development}

From a total of 1123 oocytes recovered, $52.1 \%$ were degenerated at the time of cumulus cell removal. From the remaining 525 intact oocytes, maturation rate was $74.1 \%$ (389). Of these, $254(69.8 \%)$ matured in the 22-24 h interval (Group I), 110 (30.2\%) by 28-30 h (Group II), and 13 oocytes degenerated during IVM. A total of 57 blastocysts were produced, and no significant differences in in vitro preimplantation embryo development were observed between groups (Table 1).

Table 1. Total blastocyst production.

\begin{tabular}{llcc}
\hline Maturation rate & $\mathrm{n}$ & Cleavage (\%) & Blastocyst (\%) \\
\hline Group I & 254 & $155(61.02)$ & $45(17.72)$ \\
Group II & 110 & $59(53.64)$ & $12(10.91)$ \\
\hline
\end{tabular}

\subsection{Blastocyst quality}

\subsection{Blastocyst diameter.}

The diameter of blastocysts did not differ between groups (Early: $154.31 \pm 3.2$, Late: $166.8 \pm$ 3.9).

\subsubsection{Total cell count and TUNEL+ cells}

Blastocysts from Group I had significantly more cells than embryos from Group II ( $P=0.003)$. However, there was no difference in the proportion of TUNEL+ cells between groups. Results are summarized in Table 2. 
Table 2. Total cell number and TUNEL+ cell count of ICSI blastocyst.

\begin{tabular}{ccccc}
\hline Interval & $\mathrm{n}$ & Total cells \pm S.E.M & TUNEL + Cells \pm S.E.M & $\%$ \\
\hline Group I & 8 & $243 \pm 26^{\mathrm{a}}$ & $46 \pm 9$ & $18.56^{\mathrm{a}}$ \\
Group II & 4 & $95 \pm 18^{\mathrm{b}}$ & $19 \pm 3$ & $22.32^{\mathrm{a}}$
\end{tabular}

$\%=$ average of the percentages of TUNEL+ cells.

$a, b=$ Values with different superscripts in a column are significantly different $(P<0.05)$

\subsubsection{Expression and localization of YAP1}

No significant between group difference was found in localization or global intensity YAP-1 $(\mathrm{H}=0.022, \mathrm{P}>0.05)($ Fig 1$)$.

\section{Discussion}

In this study, we demonstrated that oocytes that mature faster may have better developmental competence than those that need more time for nuclear maturation. We observed a tendency for a higher ICSI blastocyst production in experimental group I, and despite the fact that we did not observed differences in size, apoptosis or YAP1 expression, blastocyst from oocytes that matured early had significantly more cells suggesting better embryo quality.

Further research will focus on characterizing YAP1 expression in in vivo horse embryos to better understan the role of the HIPPO signaling pathway during preimplantation embryo development.

\section{Conclusion}

Our experiment indicates that oocytes with earlier nuclear maturation may have better developmental competence after ICSI and result in higher quality embryos.

\section{References}

[1] Dell'Aquila ME, De Felici M, Massari S, Maritato F, and Minoia P. Effects of Fetuin on Zona Pellucida Hardening and Fertilizability of Equine Oocytes Matured In Vitro. Biol Reprod 1999;61: 533-540

[2] Bruck I, Grerndahl C, Host T and Greve T. In Vitro Maturation Of Equine Oocytes: Effect Of Follicular Size, Cyclic Stage And Season.Theriogenology 1996; 46:75-64.

[3] Tremoleda J L, Tharasanit T, Van Tol HTA, Stout TAE, Colenbrander B, and Bevers MM. Effects of follicular cells and FSH on the resumption of meiosis in equine oocytes matured in vitro. Reproduction 2003;125:565-577.

[4] Grondahl C, Hansen TH, Hossaini A, Heinze I, Greve T, and Hyttel P. Intracytoplasmic Sperm Injection of In Vitro-Matured Equine Oocytes. Biol Reprod 1997; 57:1495-1501

[5] Kusama, K, Bai, R, Sakurai, T, Bai, H, Ideta, A, Aoyagi, Y, Imakawa, K. A transcriptional cofactor YAP regulates IFNT expression via transcription factor TEAD in bovine conceptuses. Dom animal endocrinology, 2016;57, 21-30 DOI:10.1016/j.domaniend.2016.05.002

[6] Nishioka N, Inoue K, Adachi K, Kiyonari H, Ota M, Ralston A, Yabuta N, Hirahara S, Stephenson RO, Ogonuki $\mathrm{N}$ et al The Hippo signaling pathway components Lats and Yap pattern Tead4 activity to distinguish mouse trophectoderm from inner cell mass. Dev Cell 2009;16:398 - 410 
Fig.1. Results for the YAP1 (red) and TUNEL+ cells (green) fluorescence from a blastocyst day 7.5 of culture from

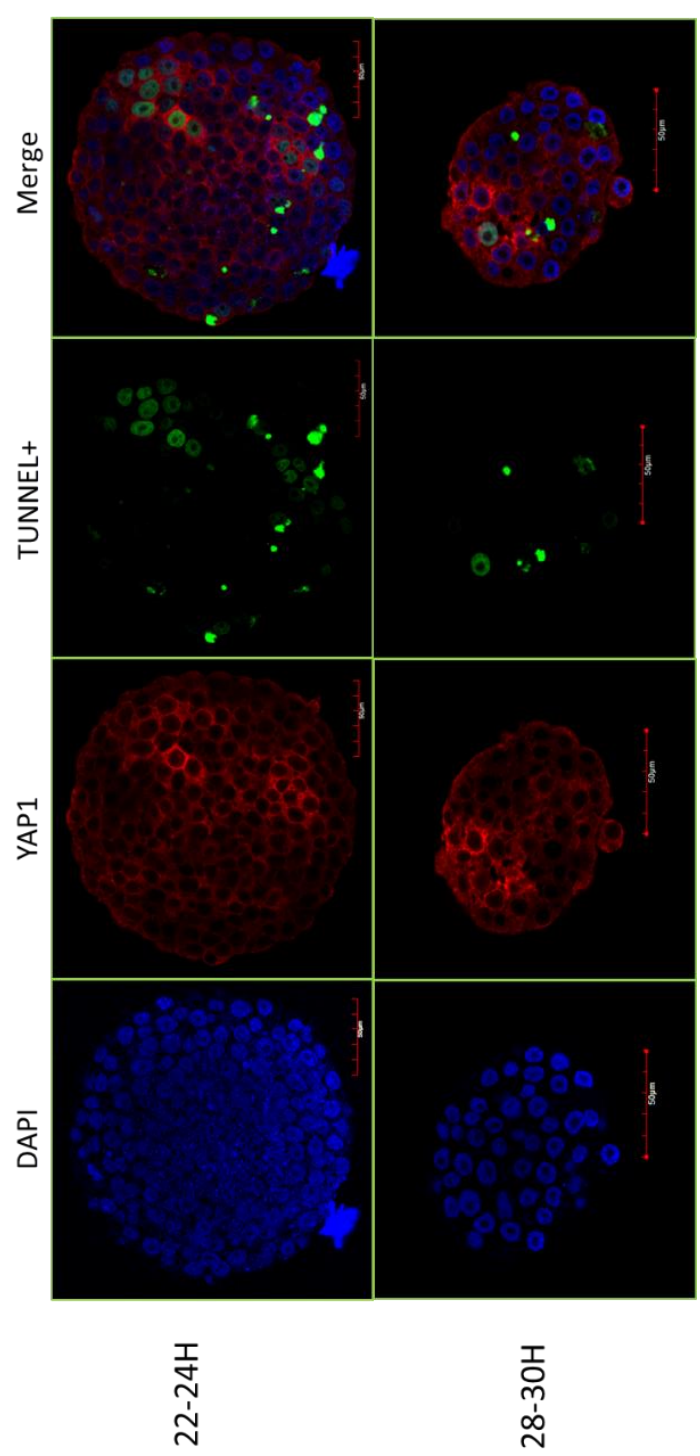
each experimental group. 